Fifth International Conference on Sustainable Construction Materials and

Technologies. http://www.claisse.info/Proceedings.htm

\title{
SUSTAINABILITY OF CONSTRUCTION MATERIALS AND BUILDINGS: AN OVERVIEW
}

\author{
B. V. Venkatarama Reddy
}

Professor, Department of Civil Engineering, Indian Institute of Science, Bangalore 560 012, INDIA, E-mail: venkat@iisc.ac.in,

\begin{abstract}
Global per capita consumption of construction materials is about 8 tonnes per year. Cement, steel, aggregates, bricks, glass, aluminium, etc. represent bulk of these materials. Built environment consumes apart from land and water, 30\% of material resources and $50 \%$ of energy resources, at the same time responsible for $40 \% \mathrm{CO}_{2}$ emissions generating $40 \%$ pollution load. Energy and material resources are essential for the construction sector. The paper presents an analysis of the consumption of energy and materials resources, the relevance of green building concepts to address the sustainability of construction sector, especially with reference to buildings. The paper traces the (a) historical developments in construction materials, (b) the magnitude of global consumption of construction materials (c) analysis of the rating systems with respect to material consumption and conservation of material resources, (d) potential of non-organic solid wastes to mitigate/augment mined raw material resources and (e) analysis of sustainability of green constructions.
\end{abstract}

Key words: Sustainability, green buildings, construction materials, energy

\section{HISTORICAL DEVELOPMENTS IN CONSTRUCTION MATERIALS}

The production of building materials and building practices have evolved through ages. The art of building construction commenced with the use of natural materials such as stones, earth and biomass. Hardly any energy expenditure in the manufacturing and the use of such natural building materials. Such natural building materials possess zero environmental costs and can go back to their native form without causing environmental damage. Some problems associated with the durability of the natural materials resulted in devising methods to produce durable building materials. The processes involved in producing durable building materials results in irreversible changes to the natural materials causing irreversible damage to the natural materials. In such processes both energy and environmental costs are involved. 
Based on the earlier studies (Reddy 2004) and the new data the Table 1 highlights the types of building materials used from the historical period to the present day. Prior to $4400 \mathrm{BC}$ the building construction was mainly dominated by the use of natural materials. The earliest example of thermal energy use in the production of building materials can be seen in the manufacture of durable materials such as the burnt clay brick (4400 BC). The lime came into picture around $4000 \mathrm{BC}$. The use of iron can be seen in $3000 \mathrm{BC}$. The first glassware products appeared in $1500 \mathrm{BC}$. The period of 500 - $300 \mathrm{BC}$ represents the use of lime-pozzolana. The $\mathrm{R} \& \mathrm{D}$ in the binding materials paved the way for the invention of Portland cement in 1824. The Portland cement and the steel brought revolutionary changes in the construction practices since early part of twentieth century. Later on, the plastics, nanomaterials, special alloys, smart materials, etc. entered the construction industry.

Table 1 - Historical developments in building materials

\begin{tabular}{|c|c|c|c|}
\hline Type of material & $\begin{array}{c}\text { Period of } \\
\text { development }\end{array}$ & Energy & \\
\hline $\begin{array}{l}\text { Natural materials } \\
\text { - Stone } \\
\text { - Soil }\end{array}$ & $\begin{array}{c}\text { Prior } \\
4400 \mathrm{BC}\end{array}$ & $\begin{array}{l}\text { Zero embodied } \\
\text { energy }\end{array}$ & $\begin{array}{c}\text { Zero } \\
\text { Embodied Carbon }\end{array}$ \\
\hline $\begin{array}{l}\text { - Adobe brick } \\
\text { - Biomass ............ }\end{array}$ & & materials & \\
\hline Burnt clay brick & $4400 \mathrm{BC}$ & \multirow{7}{*}{$\begin{array}{l}\text { Medium } \\
\text { embodied } \\
\text { energy } \\
\text { materials }\end{array}$} & \\
\hline Lime & $4000 \mathrm{BC}$ & & \\
\hline Glass & $3500 \mathrm{BC}$ & & \\
\hline Use of Iron & $3000 \mathrm{BC}$ & & \\
\hline Glassware & $1500 \mathrm{BC}$ & & \\
\hline Pozzolana & $500 \mathrm{BC}$ & & \\
\hline Lime-pozzolana & $300 \mathrm{BC}$ & & \\
\hline \multirow{3}{*}{$\begin{array}{l}\text { Modern materials } \\
\text { - Bakelite } \\
\text { - Aluminium \& other } \\
\text { metals } \\
\text { - Portland cement } \\
\text { - Plastics, polymers } \\
\text { - Smart/Nano materials } \\
\text {....... etc. }\end{array}$} & \multirow[t]{3}{*}{$\begin{array}{c}\text { After } \\
1500 \mathrm{AD}\end{array}$} & \multirow{3}{*}{$\begin{array}{l}\text { High embodied } \\
\text { energy } \\
\text { materials }\end{array}$} & \\
\hline & & & \begin{tabular}{|c} 
High \\
Embodied Carbon \\
\end{tabular} \\
\hline & & & \\
\hline
\end{tabular}

Hardly any energy was expended in the use of natural building materials pre-4400 BC period. Such materials can be designated as zero energy or zero embodied carbon materials. The later period till the industrial revolution (4400 BC to $1800 \mathrm{AD}$ ), saw the use of thermal energy for manufacturing and use of building materials. The metals, burnt clay bricks, lime and lime-based products, etc. represent some of these materials. These materials possess some amount of embodied carbon and can be classified under the medium energy consuming materials. The modern era (after 1800 AD) saw proliferation of the manufacture and use of energy intensive building materials 
(Portland cement, glass, steel, aluminium, plastics, nano-smart materials, etc.). Thus, we moved away from the zero embodied energy materials to more modern, energy intensive materials for the construction activities. It became imminent to spend more energy, emitting more carbon and consuming more natural resources by the construction sector.

These modern materials (listed in the Table 1) are energy intensive and are hauled over long distances before being used for the construction. In the context of carbon emission reductions and the issues of global warming, there is a need to pay attention to (i) energy intensity/embodied carbon of the materials, (ii) consumption of non-renewable natural resources and raw materials, (iii) recycling and safe disposal of materials at the end of life and (iv) impact on the environment. Indiscriminate use of natural resources and energy-intensive processes in the manufacture of the construction materials will not lead to the sustainable construction options. The paper focuses on certain issues pertaining to the mining of material resources, energy, carbon emissions, rating systems and sustainability of the construction practices. Also, an attempt has been made to examine the potential of non-organic solid wastes in mitigating/augmenting the demand for mined raw material resources and analysis of the green constructions with reference to the sustainability.

\section{SUSTAINABILITY AND GREENNESS}

The sustainability is associated with renewability or regeneration. With reference to the sustainability of the construction sector, it refers to the use of material resources in a renewable fashion. There are more than 200 definitions for sustainable development. An oldest definition for sustainable development can be found in Kumarappa's (1945) book entitled "Economy of Permanence". The Brundtland report (1987) provides the most quoted definition on sustainable development. The two definitions are highlighted in the Table 2.

The sustainable society is the one which manages its economic growth while keeping in focus the environment and the needs of the future generations (Kumarappa 1945). A similar definition on sustainable development has been stated in the Brundtland report (1987). The prime focus in both these definitions is on sustainable extraction of resources from the planet earth, without causing irreparable damage to the environment. The construction industry is greatly dependent upon the use of two important resources: the materials and the energy. The raw materials and the energy become essential for manufacturing the construction products, the transportation of the materials/products, and the construction processes. The raw materials extracted from the earth are processed into construction materials and then used in the construction processes. The energy is expended in the transportation of materials (raw and manufactured), manufacturing of construction products, the construction processes and the disposal at end of life. The building life cycle encompasses consumption of energy throughout its active life and the end of life disposal. 
The greenness is about decarbonisation. It refers to the changing relative amounts of carbon and hydrogen in the fuels burnt to generate energy (Bradford 2006). There are different types of fuels. The carbon to hydration ratio in some of the fuels is given in the Table 3. The firewood has the highest carbon content as compared to other fuels. When these fuels combust, the carbon and hydrogen in the presence of oxygen are responsible for releasing the energy. Only the carbon part of the fuel is responsible for undesirable emission (carbon dioxide, carbon monoxide, etc.) problems.

The greenness is all about emission reduction. There is an attempt to move towards the low carbon emission or zero carbon emission while using fuels for energy generation. Improving the energy efficiency of production/transportation systems and heating/cooling systems in built environment does not address the issues pertaining to mining of material resources and material resources depletion in the construction sector. Sustainable construction should address both the greenness and the material resource consumption.

Table 2. - Definition of sustainable development

\begin{tabular}{|l|l|}
\hline \multicolumn{1}{|c|}{ Kumarappa (1945) } & \multicolumn{1}{c|}{ Brundtland land (1987) } \\
\hline $\begin{array}{l}\text { Sustainable society: } \\
\text { Manages its economic growth without } \\
\text { causing irreparable damage to the } \\
\text { environment }\end{array}$ & $\begin{array}{l}\text { Sustainable development: } \\
\text { Meeting the needs of the } \\
\text { present without } \\
\text { - Satisfies people's needs without } \\
\text { jeopardizing the prospects of future } \\
\text { generations }\end{array}$ \\
\hline
\end{tabular}

Table 3. - Carbon to hydrogen ratio in fuels (Bradford 2006)

\begin{tabular}{|l|r|l|}
\hline Type of fuel & Carbon & Hydrogen \\
\hline Firewood & 10 & 1 \\
Coal & 2 & 1 \\
Oil & 1 & 2 \\
Natural gas & 1 & 4 \\
Hydrogen & 0 & 1 \\
\hline
\end{tabular}

\section{MATERIAL AND ENERGY RESOURCES CONSUMPTION}

\section{Material Resources}

The fundamental sustainability challenge for the construction sector and in particular for the buildings lies in managing the material/energy resources and the waste generated. This implies conservation of non-renewable/mined resources and efficiently utilising renewable resources. Particularly, in the context of future generations, consideration should be given to the usage of three different types of planetary assets (UNCHS 1990). 
(a) Finite stock of non-renewable material resources (fossil fuels, minerals, soil, stone, ore, coal, etc.)

(b) Renewable resources (solar energy, wind energy, forest produce, biomass, etc.).

(c) Capacity to absorb pollutants/by-products of human development (e.g. toxic chemicals, plastics, chlorofluorocarbons, etc.).

The planet is a host for several living organisms, of which humans form a fraction. The human societies occupy $2 \%$ of the planet's surface area but consume $75 \%$ of the planet's resources (O'Meara 1999).

The manufacture of construction materials requires two essential resources: raw materials and energy. The raw materials include soil, stone, sand, varieties of minerals and chemicals, and biomass apart from the water. Except biomass and water, all other raw materials are limited in

quantity and are mined. Hence, these materials are exhaustible.

The consumption of energy and material resources has been highlighted in Table 4 . The annual global consumption of construction materials is in excess of 60 billion t, which amounts to per capita annual consumption of about $8 \mathrm{t}$. The bulk of these materials are mined from the planet earth. It is alarming to note that aggregates used in the construction sector accounts for $80 \%$ of total construction materials consumed. The aggregates are mainly derived from mining river beds and crushing the rocks. The aggregate extraction has severe burden on the environment. Exploitation of natural stone for the aggregates can wipe out rocky outcrops or create large craters. This will further stress already dwindling natural resources and biodiversity. The cement consumption is double that of food grain consumption. The per capita annual burnt clay brick consumption touches $0.6 \mathrm{t}$. The burnt clay brick production consumes precious soil, which supports agriculture and forestry.

The major problems with the consumption of raw materials for the manufacture of construction products are permanent changes occurring to the mined raw materials. The basic raw materials undergo permanent structural or physical changes during the processing and manufacture of construction materials. One typical example is the case of burnt clay products. The burnt clay bricks/blocks, terracotta and ceramic products represent some of the burnt clay building materials. Generally, soils with high clay content (fertile soils) are used to produce such building products. In such products clay minerals present in the soil undergo structural changes during the firing process (800$1000^{\circ} \mathrm{C}$ ) resulting in the formation of water insoluble bonds. The transformed clay minerals are the binding materials in such products. The soil and clay minerals are formed due to the weathering of rocks over millions of years. Considering the geological time scales, the soil reserves on the planet earth are limited. The soils support the plant life and in turn the entire ecosystem on the earth is dependent on the plant life. The fertile soil when used for the manufacture of burnt clay products gets transformed into a nearly a rock form. Recovering clay minerals from the burnt clay product again needs millions of years of natural weathering. Therefore, depletion of soil resources can threaten the plant and animal life on the earth. 


\section{Energy Resources}

Annual per capita consumption of primary energy is about 1.8 toe (toe: tons of oil equivalent) and the per capita annual electricity generation is about 3.4 MWh. The energy expenditure causes emission/pollution. The emissions from fuel consumption depends upon the type of fuel and its carbon content. The trend is moving away from the carbon rich to the hydrogen rich fuels. There is considerable growth in exploiting renewable energy resources. The share of renewables in the total energy mix will touch $22.5 \%$ by 2020 (GlobalData energy 2018). Lion share of the renewable energy is from the solar and wind $(\sim 80 \%)$. Switching to renewable energy reduces emissions.

Table 4. - Global resources consumption

\begin{tabular}{|c|c|c|c|}
\hline \multirow[t]{2}{*}{ Type of product } & \multicolumn{2}{|c|}{$\begin{array}{c}\text { Annual } \\
\text { production/consumption } \\
(2017) \\
\end{array}$} & \multirow[t]{2}{*}{ Source } \\
\hline & Total & per capita & \\
\hline Primary energy* & 13511.2 & 1.801 toe $^{* *}$ & BP Statistical review (2018) \\
\hline Oil & mtoe & 0.616 toe & BP Statistical review (2018) \\
\hline Coal & 4621.9 mtoe & 0.498 toe & BP Statistical review (2018) \\
\hline Electricity & 3731.5 mtoe & 3.407 & BP Statistical review (2018) \\
\hline (generation) & 25551.3 twh & MWh & WSA 2018 \\
\hline Crude steel production & 1.689 billion & $0.225 \mathrm{t}$ & $\underline{\text { www.statista.com }}$ \\
\hline Food grains & & $0.349 \mathrm{t}$ & $\underline{\text { www.worldcement.com }}$ \\
\hline production & 2.62 billion $\mathrm{t}$ & $0.733 \mathrm{t}$ & concreteconstruction.net \\
\hline Cement production & 5.5 billion $\mathrm{t}$ & $6.541 \mathrm{t}$ & https://theconversation.com \\
\hline Aggregates (2015) & 48.3 billion $\mathrm{t}$ & $0.044 \mathrm{t}$ & https://cdn.cseindia.org \\
\hline Plastics (2015) & 322 million $\mathrm{t}$ & $0.592 \mathrm{t}$ & http://www.materialicasa.co \\
\hline $\begin{array}{l}\text { Burnt clay bricks } \\
\text { Ceramic tiles (2016) }\end{array}$ & $\begin{array}{l}4.5 \text { billion } t \\
160 \text { million } t\end{array}$ & $0.022 \mathrm{t}$ & $\mathrm{m}$ \\
\hline
\end{tabular}

\section{RATING SYSTEMS AND THE MATERIAL RESOURCES CONSUMPTION}

The buildings consume material and energy resources and generate wastes, promoting pollution. There are varieties of green building rating systems. The rating systems mainly addresses the following aspects.

- Site planning, location and the linkages - sustainable site development

- Design, materials and the construction aspects

- Water and waste management

- Energy consumption and generation - energy conservation

- Indoor environment quality and space conditioning

- Healthy living conditions 
- Awareness \& education

The rating systems are used as tools to quantify the energy and resources consumption in the buildings, ultimately encouraging pollution mitigation and waste management. The process adopted in rating the buildings is biased towards energy consumption and energy generation in a building system. The weightage assigned to different aspects of buildings for rating a building using few selected green rating systems is highlighted in the Table 5. The weightage assigned to the materials and construction methods is in the range of $6-13.5 \%$, whereas the weightage for energy related issues is in the range $39-57 \%$.

Table 5. - Weightage assigned in different rating systems

\begin{tabular}{|l|c|c|c|}
\hline \multirow{2}{*}{ Parameter } & \multicolumn{3}{|c|}{ Weightage } \\
\cline { 2 - 4 } & LEED-USA & BREEAM - UK & GRIHA -India \\
\hline $\begin{array}{l}\text { Materials, and construction } \\
\text { methods }\end{array}$ & $6-9 \%$ & $13.5 \%$ & $10 \%$ \\
\hline $\begin{array}{l}\text { Energy } \\
\text { (consumption/generation, Indoor } \\
\text { environment quality, space } \\
\text { conditioning) }\end{array}$ & $57 \%$ & $39 \%$ & $50 \%$ \\
\hline
\end{tabular}

Based on the data presented in the Table 5 and analysis of the rating systems, the limitations of the rating systems can be listed as follows.

- Rating systems are efficiency based - not effectiveness based. Advocate the use of energy efficient devices but its effective utilization is not questioned.

- Appreciate the use of the local materials but their significance on rating is inadequate. They are unquantified and no scientific basis for evaluation

- Irrational comparison between building materials and design, i.e. evaluation compared based on the performance of the material (for example insulations or finishes, viz., bamboo \& aluminum/glass placed in the same category)

- Zero-energy can be high-energy. The embodied/process energy and delayed (energy) payback is not accounted properly. High O \& M implications (eg. Solar PV) not highlighted.

- The energy in buildings encompasses embodied energy, transportation energy, energy for construction, energy for operation and maintenance, and finally energy for the demolition and recycling/disposal (Sengupta 2008, Praseeda et al. 2015). These different aspects of energy expenditure lack clarity in the rating systems.

The current rating systems lay too much emphasis on energy conservation and pollution reduction. The rating systems attempt to link the concept of green buildings to sustainable construction. There is little or less emphasis on (a) conservation of dwindling basic material resources and (b) environmental damage due to indiscriminate mining of materials resources from the planet earth. The construction sector is surviving on the mined material resources, anything mined is un-sustainable, therefore sustainable construction in the current scenario is a mirage. 


\section{RAW MATERIALS EXTRACTION/MANAGEMENT}

The utilization of mined raw materials from the planet earth for the construction, can never lead to the construction sector becoming sustainable. The over exploitation of the raw material resources and the widespread use of energy-intensive materials can drain the energy and material resources and can adversely affect the environment. Some of the possible options for addressing the issues on depleting materials wealth due to the manufacture of construction materials are as follows.

a) Use the materials judiciously and completely exploit the potential of the material.

b) Effect minimum changes to the natural materials during the production processes, such that the discarded materials can easily go back to their native state with minimum environmental costs. A simple example is the use of earthbased materials where the soil is not fired/burnt, thereby conserving the natural clay minerals in the soil. Such products when discarded after the end of the life of the product, can easily be recycled as natural soil.

c) Recycle the non-organic solid wastes into the construction products. The industrial and mining activities generate huge quantities of non-organic solid wastes.

d) Encourage the use of the construction products from the renewable materials. The biomass is a renewable and carbon neutral resource. It is available in woody and non-woody forms. Traditionally, biomass in various forms has been successfully used for the construction of buildings. Processed timber, glue laminated timber/bamboo, plywood panels, wood based composite panels, bamboo mat, bamboo and wooden poles, etc. represent different forms of woody biomass used in the construction sector. Except the thatch, the straw bale construction and the fibre reinforced earth, there is hardly any application for non-woody biomass in the construction. There is a great challenge in developing structural materials using non-woody biomass as well as agroresidues. The biomass-based construction materials are the real renewable and green materials. Such materials can be grown without threatening the food security. There is an urgent need for rigorous $R \& D$ efforts to utilize the biomass for the manufacture of construction materials for both structural and non-structural applications.

\section{RECYCLE NON-ORGANIC SOLID WASTES INTO BUILDING PRODUCTS}

The construction industry heavily depends upon the mined raw materials and hence the depletion of material resources is imminent. The construction sector is growing at an alarming rate in countries such as China, India and other countries. Meeting the demand for construction products encourages mining of the raw material resources. Therefore, it becomes essential to explore alternative resources to satisfy the demand for raw materials. In this context recovery and recycling of non-organic solid wastes (NOSW) becomes essential. Large quantities of non-organic solid wastes are being generated by the industrial and mining activities. The annual global production of the solid wastes is in excess of 12 billion t (Asokan, et al. 2007 and 2009). These include 
pulverized fuel ash, mine tailings, coal mine wastes, slag, marble dust, kiln dust, red mud, construction and demolition wastes, etc. There are huge quantities of accumulated NOSW over several decades (wastes from thermal power plants, coal mine wastes, ore tailings of several mines, etc.). The recycling of NOSW into construction products can mitigate the pressure on the depleting raw materials resources due to mining. Investigations by Ullas and Reddy (2009), Xuping Li (2008), Robinson et al. (2004), Padmini et al. (2009), Khalaf and DeVenny (2004) and many other studies are some attempts in this direction. Non-organic solid wastes can become the resources in future for the manufacture of construction materials across the globe.

\section{SUSTAINABILITY OF GREEN BUILDINGS}

The buildings need material and energy resources. The mass of the urban dwellings in India is in the range of $3-4 \mathrm{t} / \mathrm{m}^{2}$ (Praseeda 2014). The embodied energy is in the range $1.2-11 \mathrm{GJ} / \mathrm{m}^{2}$ (Praseeda et al. 2016). The operational energy (OE) in the buildings differ widely in conditioned and unconditioned buildings. The range for $\mathrm{OE}$ is $0.50-$ $59 \mathrm{GJ} / \mathrm{m}^{2}$ per annum (Praseeda et al. 2016). The sustainability issues of the buildings are mainly influenced by the energy and material resources consumption and can be pictorially visualized as shown in the Fig. 1. The energy expenditure in buildings is associated with embodied and operational energy. The former one is a one-time investment and the later one is a recurring one. Both these forms of energy in buildings constitute life cycle energy (LCE). The green building concepts manly focus on LCE aspects. The conservation of energy and minimising energy consumption in buildings addresses only a small component of the sustainable building. The major issue needing attention in sustainable buildings or constructions is the use of mined and nonrenewable material resources. Therefore, all green buildings need not be sustainable options. The real sustainable building/construction is the one which uses renewable materials/renewable energy or passively conditioned systems, having least impact on the environment.

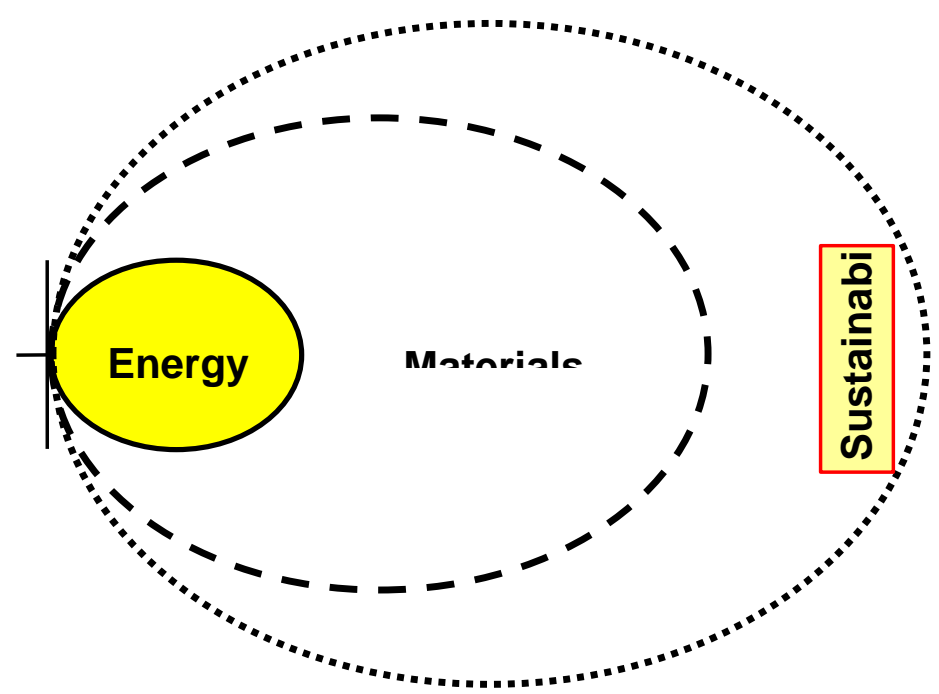

Fig. 1 - Share of sustainability parameters in buildings 


\section{CONCLUDING REMARKS}

A review of some facts about sustainability of construction sector and in particular about buildings was discussed. The sustainability of construction sector should encompass two major issues: the energy and the material resources. The annual per capita consumption of construction material is alarming at $8 \mathrm{t}$. The lion share of it is from the aggregate's consumption and the construction materials hail from the mined resources from the planet earth. The green building rating systems address only a part of the sustainability aspect, with very little emphasis on consumption of dwindling mined material resources. In the business as, usual scenario the construction sector is surviving on the mined materials, which is unsustainable. Due attention should be paid to evolving renewable construction materials and recycling the non-organic solid wastes.

\section{REFERENCES}

Asokan P., Saxena, M., Shyam, R., Asolekar, S. and Anusha S. (2009). "Cross sector recycling opportunities", Proceedings of the International seminar on waste to wealth, Nov. 12-13, New Delhi, India.

Asokan P., Saxena, M. and Asolekar, S.R. (2007). "Solid wastes generation in India and their recycling potential in building materials", Building and Environment, $42,2311-2320$.

BP Statistical review of world energy, 67th ed., June 2018, London, UK

Bradford Travis. (2006). Solar revolution - the economic transformation of the global energy industry, The MIT Press, Cambridge USA.

BREEAM - UK, breeam@bre.co.uk

Brundtland report. (1987). "Report of the World Commission on Environment and Development - Our Common Future", United Nations 1987

GlobalData Energy (2018) https://www.power-technology.com/comment/renewableenergy-reach-22-5-share-global-power-mix-2020/

GRIHA India, "The National Rating System for Green Buildings", Association for Development and Research of Sustainable Habitats (ADaRSH), The Energy and Resource Institute (TERI), New Delhi, India

https://theconversation.com/the-world-of-plastics-in-numbers-100291

https://cdn.cseindia.org/docs/photogallery/slideshows/TP-cleaner-brick-production20171211-15-Overview-of-Brick-Kiln-Sector-Environmental-issues-NivitKuma.pdf

http://www.materialicasa.com/file/Home/materialicasa/pdf/tileinternational/2017/3/042_049\%20Statistic\%20PROD\%20CONS\%20Mondial e.pdf

Khalaf, F. M. Alan, S. De Venny. (2004). "Recycling of demolished masonry rubble as coarse aggregate in concrete: Review", Journal of Materials in Civil Engineering, 16(4), 331-340.

Kumarappa, J. C. (1945). Economy of permanence, Sarva-seva-sangh Prakashan, Varanasi, India 
LEED-USA, U.S. Green Building Council, Washington DC, USA (https://new.usgbc.org/leed)

O’Meara. (1999). "Reinventing Cities for People and the Planet", Washington, D.C., Paper \#147, Worldwatch Institute.

Praseeda, K. I., Venkatarama Reddy, B. V. and Mani, M. (2015). "Embodied energy assessment of building materials in India using process and input-output analysis", Energy and Buildings, 86, $677-686$.

Padmini, A.K., Ramamurthy, K. and Mathews, M.S. (2009). "Influence of parent concrete on the properties of recycled aggregate concrete", Construction and Building Materials, 23, 829-836.

Praseeda, K. I. (2014). "Studies into Embodied and Operational Energy in Traditional and Conventional Residential Buildings in India", Ph. D. thesis, Department of Civil Engineering, Indian Institute of Science, Bangalore, India.

Praseeda, K. I., Venkatarama Reddy, B. V. and M. Mani, (2016). "Embodied and operational energy of urban residential buildings in India", Energy and Buildings, 110, $211-219$.

Robinson Jr. G.R., David, M. and Helen H. (2004). "Recycling of construction debris as aggregate in the mid-Atlantic region USA", Resources Conservation and Recycling, 42, 275-294.

Reddy, B. V. V., (2004). "Sustainable building technologies", Current Science, 87(7), $899-907$

Sengupta, N. (2008). "Use of cost-effective construction technologies in India to mitigate climate change", Current Science, 94(1), 38-43.

UNCHS (1990). "People, Settlements, Environment and Development: Improving the living environment for a sustainable future", Intergovernmental meeting on Human Settlements and Sustainable Development, The Hague.

Ullas, S.N. and Reddy B.V.V. (2009). "Iron ore tailings as sand substitute in masonry mortar", Proceedings International Seminar on Waste to Wealth, Nov. 12-13, New Delhi India, 151-155.

Xuping, Li. (2008). "Recycling and reuse of waste concrete in China, Part I. Material behaviour of recycled aggregate concrete", Resources Conservation and Recycling, 53, 36-44.

World steel association (WSA). (2018). World steel in Figures, Brussels Belgium 